$911.3: 796.5$

ьвівський н ціон льний університет імені в н вул. . орошенк , 41, м. ввів, 79000, кр їн , тел. (0322) 394-769

осліджено готельне господ рство ьвівщини і головного туристичного центру хідного регіону кр їни - ьвов . ро н лізов но головні пок зники розвитку сфери готельних послуг ьвівської обл. $з$ період 2000-2009 рр. озглянуто основні н прями вдоскон лення готельної індустрії регіону, у тому числі для успішного проведення чемпіон ту вропи з футболу у 2012 p.

лючові слов : готельне господ рство, туристичн інфр структур , готель, готельні послуги, кількість обслужених гостей, місткість готелів, коефіцієнт місткості підприємств готельного господ рств , чемпіон т вропи з футболу.

ьвів є одним із н йбільших туристичних центрів хідної кр їни. ін прив блює зн чну кількість внутрішніх т іноземних туристів. игідне геогр фічне положення міст , б г тство його історико-культурної сп дщини створюють широкі можливості для розвитку туристичного бізнесу - одного з основних пріоритетних н прямів міської економіки. ож розвинут готельн інфр структур є в жливим чинником, що визн ч $є$ обсяги і н прямленість туристичних потоків в’їзного т внутрішнього туризму.

ш мет - про н лізув ти н явні тенденції розвитку готельної субг лузі туристичного комплексу ьвов т ьвівської обл., виявити перспективні іннов ційні н прями їі розвитку у ст.

Йгрунтовніше проблем тик формув ння індустрії гостинності т ринку готельних послуг кр їни т іiі регіонів розкрит у низці спеці льних досліджень . г фонової, . йлик , . юбіцевої, . рсекін , . ініч, . оглєв , . к ченко, . едорченко й 6 г тьох інших учених. еред ост нніх пр ць, у яких озн чено н явні проблеми й про н лізов но перспективи розвитку готельного господ рств кр їни, н звемо пр ці . руль, . льської, . ндяк , . нтонюк, . нич . [8-11] т ін.

істо ьвів є потужним туристичним центром, де ктивність розвитку ринку готельних послуг зн чно випередж є темпи розвитку готельного господ рств в інших p йон х т міст х обл сті. експертними д ними місто відвідують у середньому впродовж ост нніх років пон д 500 тис. туристів щорічно, і цей пок зник неухильно зрост $€$ [1].

ме тому пит ння розвитку туристичної інфр структури відповідно до міжн родних ст нд ртів м ють першочергове зн чення. скільки ж місто ьвів прийм є м тчі вро-2012 і до поч тку чемпіон ту з лишилось менше року, то дед лі кту льнішим ст є пит ння про готовність з кл дів готельного господ рств - однієї з н йв жливіших скл дових туристичного бізнесу.

ідповідно до вимог , до футбольного чемпіон ту ьвів повинен з безпечити 1315 номерів у готелях рівня п’ять зірок, 1020 - рівня чотири зірки і 2740 номерів - у

(С) тецюк ., 2012 
три зіркових готелях. ісля реконструкції т переобл дн ння студентських гуртожитків місто під ч с проведення чемпіон ту отрим є дод ткові місця (близько 21 700).

формов но повну б зу д них об'єктів розміщення для всіх вболів льників, що є основою для єдиної системи бронюв ння номерів у 2012 р., т розроблено к т лог готелів для цільових груп ․ онцепція з розміщення вр ховує усі з кл ди готельного господ рств н шляху вболів льників від кордону з до ьвов , у меж х міст , т кож у уцьку т в но- $p$ нківську, де розт шов ні резервні еропорти, і н шляху від ьвов до иєв - 3 г лом пон д 750 об'єктів [2].

жливими проблем ми є поліпшення якості н д ння готельних послуг, р ціон льне т ефективне використ ння н явної м тері льно-технічної б зи, підвищення рівня кв ліфік ції ф хівців готельної сфери, створення сприятливих умов для з лучення інвестицій т под льшого розвитку г лузі, вр ховуючи суч сні тенденції т світовий досвід в орг ніз ції готельного сервісу.

місті розроблено низку в жливих стр тегій т прогр м, які м ють особливе зн чення для створення суч сного конкурентоспроможного готельного господ рств 3 ур хув нням збереження його рхітектурної сп дщини т модерніз ції інфр структурних мереж.

ьвівщин у 2009 і 2010 рр. посіл друге місце в кр їні з кількістю приїжджих, обслужених підприємств ми готельного господ рств обл сті. ослуг ми готельних 3 кл дів у 2010 р. скорист лися 353,2 тис. осіб, що н 20,7 \% більше, ніж у 2009 р. (водноч с н 4,5\% менше, ніж у 2008 р.), що тоді пояснюв ли фін нсовою кризою. ин міку кількості обслужених гостей підприємств ми готельного господ рств обл стей кр їни впродовж 2009 р. відобр жено н рис. 1.

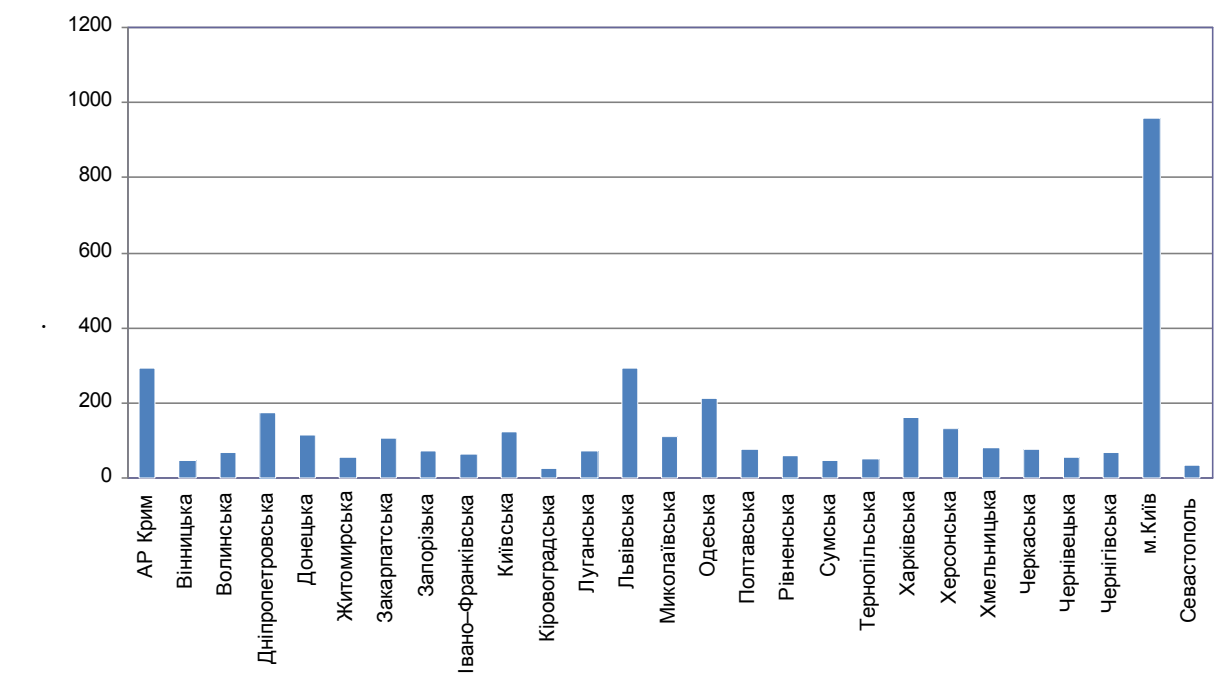

ис. 1. ількість обслужених гостей з кл д ми готельного господ рств в обл стях кр їни, 2009 р., тис. осіб.

зн чимо, що впродовж ост нніх десяти років середньорічний коефіцієнт використ ння місткості з собів розміщення ьвівщини щорічно змінюв вся. 2000 р., цей пок зник зріс від 0,19 до 0,21 у 2003-2004 pр., у 2005-2006 ст новив 0,18, у 2007 зрост в 
i досяг 0,21, у 2008-2009 pp. спостережено тенденцію до зниження коефіцієнт використ ння місткості готелів, який ст новив, відповідно, 0,22 т 0,18. ин міку коефіцієнт використ ння місткості підприємств готельного господ рств ьвівщини впродовж 2000-2009 pр. пок з но н рис. 2.

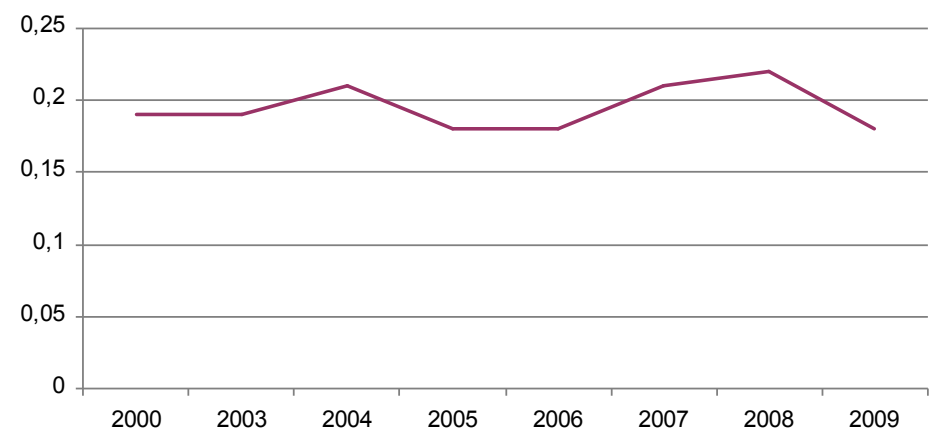

ис. 2. оефіцієнт використ ння місткості підприємств готельного господ рств ьвівщини у $2000-2009 \mathrm{pp}$

окрем, н голосимо н сезонності пок зників з в нт ження готелів м. ьвов . йвищими ці пок зники є впродовж весни т осені (тр вень-вересень) у період високого сезону, низький сезон, що прип д є н листоп д-лютий (з винятком першої половини січня н іздвяні свят т овий ік, коли до ьвов приїждж є зн чн кількість туристів). ротягом липня і серпня (сезон літніх відпусток) рівень з в нт ження готелів теж дещо знижується.

Йже чверть приїжджих (82,9 тис. осіб) ст новили іноземні гром дяни. еред іноземців, які зупинялися у готелях обл сті, перев ж ли гром дяни ольщі, осійської едер ції, імеччини, , ілорусі (рис. 3). г лом готельні 3 кл ди ьвівщини прийняли гром дян 103 кр їн світу.

2010 р. мереж готельних з кл дів н ьвівщині продовжув л розвив тися. орівняно з 2005 р. кількість готелів т інших місць для тимч сового прожив ння зросл більш ніж удвічі й н кінець 2010 р. ст новил 472 одиниці (18,8 тис. місць, 8288 номерів).

собливо ктивно розвив ється прив тний готельний бізнес. 2010 р. 313 готельних з кл дів ьвівщини н леж ли фізичним особ м-підприємцям (відповідно, 11,9 тис. місць, 5359 номерів).

г лом н ьвівщині діяло 48 к тегоров них готелів, 3 них 8 чотиризіркових, 29 тризіркових, 10 двозіркових т один однозірковий (ст ном н 1.01.2010р.).

оходи готельних з кл дів від н д ння послуг з прожив ння у 2010 р. ст новили 320,3 млн грн, з них 49,8 млн грн (15,5\%) - доходи з кл дів фізичних осіб-підприємців [3].

поч ток 2010 р. у м. ьвові н лічув ли 81 готельний 3 кл д н 2,7 тис. номерів, у м. руск вці - 52 з кл ди н 1,48 тис. номерів, у смт хідниця - 32 з кл ди н 510 номерів, у колівському р-ні - 92 з кл ди н 1,2 тис. номерів [4, с.16]. вже 1.01 .2011 у м. ьвові пр цюв ло 92 готельні з кл ди н 2,9 тис. номерів, у м. руск вці - 54 з кл ди н 1,51 тис. номерів, у смт. хідниця - 36 з кл дів н 0,7 тис. номерів, у колівському р-ні - 99 з кл дів н 1,3 тис. номерів [5, с. 13]. 


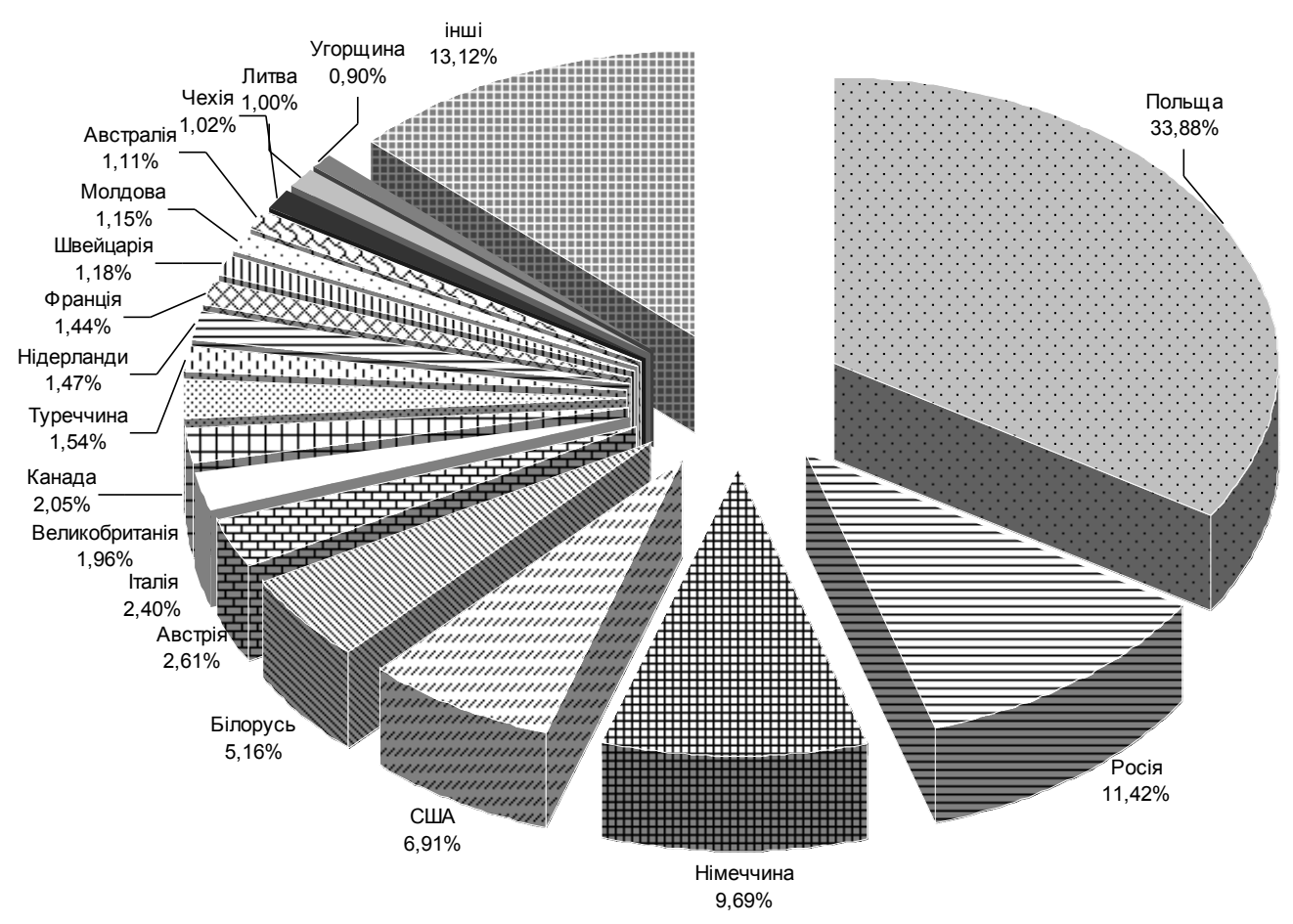

ис. 3. ром дянство туристів, що прожив лиі в готелях ьвівської обл. у 2009 р.

2000 р. простежується позитивн тенденція до зрост ння кількості з кл дів розміщення як у ьвівській обл. з г лом, т к і в обл сному центрі зокрем (див. т блицю).

отельне господ рство м. ьвов [12, с. 64]

\begin{tabular}{|c|l|l|l|l|l|l|}
\hline оки & \multirow{2}{*}{$\begin{array}{l}\text { ількість } \\
\text { готелів, } \\
\text { одиниці }\end{array}$} & $\begin{array}{l}\text { ількість } \\
\text { номерів, } \\
\text { одиниці }\end{array}$ & $\begin{array}{l}\text { бслужено } \\
\text { приїжджих, } \\
\text { осіб }\end{array}$ & $\begin{array}{l}\text { бслуже- } \\
\text { но інозем- } \\
\text { ців, осіб }\end{array}$ & осьоги, тис. грн. & $\begin{array}{l}\text { від обслугову- } \\
\text { в ння } \\
\text { іноземців }\end{array}$ \\
\hline 2000 & 43 & 2351 & 148037 & 26310 & 20286,9 & 10939,9 \\
\hline 2005 & 54 & 2811 & 189353 & 53147 & 56696,8 & 22749,4 \\
\hline 2006 & 62 & 2917 & 223123 & 54347 & 76196,7 & 28809,9 \\
\hline 2007 & 71 & 3129 & 232426 & 61986 & 132512,8 & 38806,6 \\
\hline 2008 & 75 & 3298 & 278840 & 77469 & 179603,3 & 57577,6 \\
\hline 2009 & 81 & 3456 & 211402 & 62244 & 195536,1 & 62810,1 \\
\hline
\end{tabular}

ише у ьвові впродовж 2010 р. відкрито низку нових готелів, ктивно трив є реконструкція н явних 3 кл дів. львівському ринку нічліжних послуг з'являються 3 кл ди міжн родних готельних мереж, які користуються визн ною популярністю в іноземних туристів-індивіду лів т бізнес-туристів.

січні 2010 р. $з$ пр цюв в готель "Reikartz воржец ьвів" (вул. ородоцьк , 107) бельгійського опер тор "Reikartz Hotels \& Resorts", в січні 2011 р. відкрито "Reikartz едів ль ьвів"н вул. рук рській. 
зн чимо, що нові готельні підприємств , які з'являються н терен х н шого міст , - це невеликі готелі до 50 номерів ("Reikartz воржец ьвів" - 52 номери, "Reikartz едів ль ьвів" - 23 номери).

другій половині 2010 р. у ьвові після реконструкції будівель відкрилися готель “ дем” (20 комфорт бельних номерів різних к тегорій), ” опен” (16 номерів), “ уп в ” (13 номерів), “ ихів” (45 номерів).

тр вня 2011 р. трив є реконструкція у будівлі колишнього готелю “ иїв” (вул. ородоцьк , 15). г лом готель під новою н звою “ сторія” розр хов ний н 4 зірки т 46 номерів. отують до відкриття 4-зірковий 49-кімн тний готель "Nobilis" у діло-вому центрі ьвов (вул. редр , 7). роводять роботи з розширення площ готелів “ вейц рський”, “ еополіс", "Reikartz едів ль ьвів” т “ інт ж”. кщо н поч ток 2011 р. споруджув ли нові 465 об'єктів в обл сті, то з них 21 об'єкт - це будівництво готелів т рестор нів.

ез сумніву, у р мк х чемпіон ту н йбільш популярними будуть готелі к тегорії дві-чотири зірки, т кож п рт-готелі т хостели, кількість яких ост нніми рок ми постійно зрост є. йперспективнішими сегмент ми готельної індустрії є сектор міжн родних брендів середнього кл су $(3 *, 3+*)$ т розвиток м лих бутік-готелів кл су $3-4 *$.

жливою і не вирішеною є проблем пристосов ності готелів до потреб осіб з обмеженими фізичними можливостями. еоднор зово порушув ли пит ння про пристосов ність готелів до потреб осіб з обмеженими фізичними можливостями т ініціюв ли викон ння досліджень. прикл д, н поч тку 2011 р. проведено моніторинг 57 готелів ьвов . його результ т ми з'ясов но, що лише сім готелів можуть прийняти дев'ять осіб з інв лідністю [6].

тже, основними проблем ми розвитку готельного господ рств ьвівщини треб визн ти низьку з в нт женість готелів, не проходження сертифік ції н відповідність певній к тегорії т вимог м безпеки, невідповідність в ртості прожив ння рівню комфорту і сервісу, довготрив лість ре ліз ції готельних інвестиційних проектів.

умов високих цін н послуги готелів у ьвові ктивно розвив ється ринок т ких льтерн тивних видів прожив ння, як короткотермінов оренд п рт ментів, що створює зн чну конкуренцію готельним з кл д м.

собливості розвитку готельного господ рств ьвівщини т обл сного центру д ють підст ви для виокремлення пріоритетних н прямів розвитку готельного господ рств ьвов, с ме:

- підвищення рівня н д ння готельних послуг т кв ліфік ції персон лу готелів у місті;

- розвитку готельної інфр структури відповідно до вимог міжн родних ст нд ртів;

- розвитку інвестиційної ктивності т конкуренції у сфері готельної індустрії;

- ктивіз ції співпр ці викон вчих орг нів міської р ди з суб'єкт ми готельного господ рств ;

- $з$ безпечення ефективного функціонув ння готельного господ рств відповідно до чинної норм тивно-пр вової б зи, розробк т прийняття регуляторних ктів, спрямов них н вирішення проблем у сфері готельного господ рств в місті. 
1. $ж$ люк. оль туризму в економіці ьвов / . ж люк, . обз рев, . ундор [ лектронний ресурс]. ежим доступу: http: //www.city-institute.org

2. ьвів прийм є вро [ лектронний ресурс]. ежим доступу: http://www.city-adm.lviv.ua/euro2012/hotels

3. ьвівськ обл сть є одним із лідерів готельного бізнесу / рес-реліз оловного упр вління ст тистики у ьвівській обл сті від 27.05.2011. - № 82. - 2 с.

4. рогр м соці льно-економічного т культурного розвитку ьвівської обл сті н 2010 р. / ьвівськ обл сн р д .- ьвів, 2009. - 88 с.

5. рогр м соці льно-економічного т культурного розвитку ьвівської обл сті н 2011 р. / ьвівськ обл сн р д .- ьвів, 2010. - 76 с.

6. епристосов ність готелів ьвов до потреб осіб з обмеженими фізичними можливостями [ лектронний ресурс]. ежим доступу:

http://www.semesta.lviv.ua/index.php?option=com_content\&view=article \&id=271:2011-07-21-12-2008\&catid=1:2010-04-18-12-38-13\&Itemid=3

7. отельне господ рство т туризм у ьвівській обл сті: ст тист. зб. / оловне упр вління ст тистики у ьвівській обл сті. - ьвів, 2010. - 112 с.

8. руль . . снови готельної спр ви : н вч. посібник/ . . руль. . : , 2011. -368 с.

9. льськ . . рг ніз ція готельного обслуговув ння : підручник / . . льськ , . . н ндяк, . . нько. - . : н ння, 2011. - 366 с.

10. льськ . . іжн родний туризм і сфер послуг : підручник / . . льськ , . . н тонюк, . . нич. - . : н ння, 2008. - 661с.

11. льськ . . отельний бізнес: теорія т пр ктик / . . льськ , . . 2010. -472 c.

12. екре ційний потенці л ьвівщини: ст тист. зб. / оловне упр вління ст тистики у ьвівській обл сті. - ьвів, 2011. - 98 с.

13. Ст тистичний щорічник кр їни з 2004 рік [ред. . с уленко]. . . онсульт нт, 2005. $592 \mathrm{c}$.

14. т тистичний щорічник кр їни з 2007 рік [ред. . . с уленко]. .: онсульт нт, 2008. 572 c.

15. т тистичний щорічник кр їни з 2009 рік [ред. . с уленко]. . : онсульт нт, 2010. $567 \mathrm{c}$.

m ття: н дійшл до редколегї 07.09.2011

прийнят до друку 20.09.2011

\section{THE HOTEL INDUSTRY IN LVIV: MODERN TRENDS OF PROGRESS}

\section{O. Stetsyuk}

Ivan Franko National University of Lviv, . Doroshenko St., 41, UA - 79000 Lviv, Ukraine, tel. (0322) 394-769

The hotel industry of Lviv region and the main tourist centre of the Western region of Ukraine Lviv are investigated. The basic indicators of development of hotel services in Lviv area is analyzed during 2000-2009. The main stream of improvement of the regional hotel industry is expected, including for successful carrying out of the European Football Championship in 2012.

Key words: hotel industry, tourist infrastructure, hotel, hotel services, quantity of visitors, capacity of hotels, coefficient of capacity of the enterprises, the European Football Championship. 


\section{- тецюк}

ввовский н цион льный университет имени в н р нко,

ул. . орошенко, 41, г. ьвов, 79000, кр ин, тел. (0322) 394-769

сследов но гостиничное хозяйство ьвовской обл. и гл вного туристического центр п дного регион кр ины - ьвов . ро н лизиров но основные пок з тели р звития сферы гостиничных услуг ьвовской обл. 3 период 2000-2009 гг. зложено гл вные н пр вления усовершенствов ния гостиничной индустрии регион, в том числе для успешного проведения чемпион т вропы по футболу в 2012 г.

лючевые слов : гостиничное хозяйство, туристическ я инфр структур , гостиниц , гостиничные услуги, количество принятых гостей, вместимость гостиниц, коэффициент вместимости предприятий гостиничного хозяйств , чемпион т вропы по футболу. 